\title{
1997-98 Annual Report
}

\section{Association Of}

\section{O L L E G E}

\section{\& RESEARCH}

\section{LIBRARIES}

A D I VISION OF THE AMERICAN LIBRARY ASSOCIATION

\section{ACRL's Mission}

he Association of College and Research Libraries (ACRL) provides leadership for development, promotion, and improvement of academic and research library resources and services to facilitate learning, research, and the scholarly communication process. ACRL promotes the highest level of professional excellence for librarians and library personnel in order to serve the users of academic and research libraries.

\section{VALUES FOR THE ELECTRONIC}

\section{INFORMATION AGE}

http://www.ala.org/acrl.html 


\title{
Message from the President
}

\author{
W. LEE HisLe \\ ACRL's 59TH PRESIDENT
}

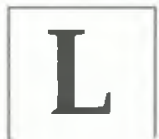

et me say first what an honor and privilege it was to serve as the $5^{\text {th }}$ President of the Association of College and Research Libraries during the past year. Members and ACRL leaders worked hard and accomplished a great deal. Highlights include:

\section{- A year-long focus on the values of librarianship}

Many members focused on the values of librarianship and the challenges to those values in an electronic information age. Values were considered during my chapter visits, in Midwinter discussions,

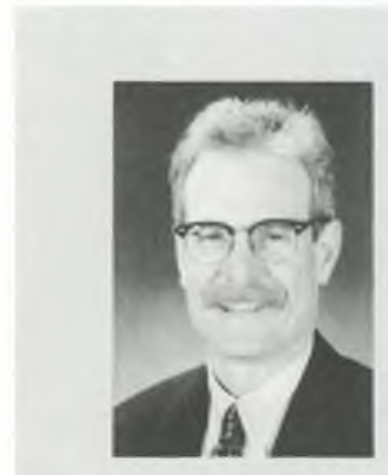

W. Lee Hisle in articles and editorials in CERL News and CERL, and culminated in the President's Program at ALA Annual Conference. The program, "The Value of Values: Changes and Continuities as We Face the New Millennium," was very successful; the keynote speaker, William Gass, inspired all who attended. (Video copies of the program are available for interlibrary loan from the ALA Library.)

- The Association's new emphasis on legislative and public policy advocacy

For the first time, an ACRL staff member was assigned responsibility to coordinate legislative advocacy. In addition, the ACRL Board adopted the first ACRL Legislative Agenda in January. At the ALA Legislative Day in May, the first coordinated activity specifically for academic librarians was held. Improved communication between ACRL, the Association of Research Libraries, and the ALA Washington Office helped highlight legislative concerns of common interest to academic librarians. Finally, a successful preconference on "Advocacy Training for Academic Librarians" was held at the ALA Annual Conference. Plans are being completed now for a Midwinter Meeting caucus and additional activities during ALA Legislative Day next spring.

- The continued development of professional education activities to meet member needs

The first ACRL Regional Institute, focusing on leadership, was successfully held in the spring. Another first, the ACRL / American Association of Higher Education (AAHE) Higher Education Issues Forum was held during AAHE's National Conference in March. Twenty-one provosts attended the highly praised session. One of the most important actions of the year was ACRL's support for the Institute for Information Literacy (IIL), funding its Advisory Committee to plan the initiatives and initial 


\section{Message from the President}

programs. At the ALA Annual Conference, three preconferences were offered along with 18 conference programs, reflecting the variety of interests of our membership.

\section{- ACRL's sound fiscal situation}

Significant funds were added to the ACRL and CHOICE endowments during the year. In addition, two alternative revenue sources were identified: the Friends of ACRL, to be launched in 1998, and a new publication, Academic Libraries: Trends and Statistics. Finally, revenues for the year were significantly more than expected, while expenses were significantly less. ACRL will have the resources to continue serving its members in the near and long-term future.

The year of my presidency passed quickly and I value all the associations I made. I offer my thanks to the members and ACRL leaders, and especially to the ACRL staff, who helped make this year so enriching for our membership.

\begin{tabular}{|c|c|c|c|c|c|}
\hline \multirow[b]{2}{*}{$\begin{array}{c}\text { ACRL } \\
\text { Sections }\end{array}$} & \multicolumn{4}{|c|}{ ACRL MEMbership Statistics } & \multirow[b]{2}{*}{$\begin{array}{c}\begin{array}{c}\text { \%increase/ } \\
\text { decrease }\end{array} \\
\end{array}$} \\
\hline & Personal & $\begin{array}{c}\text { Organizational/ } \\
\text { Special }\end{array}$ & $\begin{array}{l}\text { Aug. } 1998 \\
\text { Total }\end{array}$ & $\begin{array}{c}\text { Aug. } 1997 \\
\text { Total }\end{array}$ & \\
\hline ACRL & 9,634 & 982 & 10,616 & 10,779 & $-1.51 \%$ \\
\hline AAMES & 368 & 65 & 433 & 444 & $-2.48 \%$ \\
\hline AFAS & 249 & 26 & 275 & 290 & $-5.17 \%$ \\
\hline ANSS & 501 & 73 & 574 & 621 & $-7.57 \%$ \\
\hline ARTS & 780 & 96 & 876 & 889 & $-1.46 \%$ \\
\hline CJCLS & 895 & 229 & 1,124 & 1,133 & $-0.79 \%$ \\
\hline CLS & 1,898 & 294 & 2,192 & 2,284 & $-4.03 \%$ \\
\hline EALS & 616 & 14 & 630 & 621 & $1.45 \%$ \\
\hline EBSS & 1,061 & 186 & 1,247 & 1,317 & $-5.32 \%$ \\
\hline DLS & 1,019 & 57 & 1,076 & 947 & $13.62 \%$ \\
\hline IS & 3,773 & 422 & 4,195 & 4,253 & $-1.36 \%$ \\
\hline LPSS & 639 & 89 & 728 & 755 & $-3.58 \%$ \\
\hline RBMS & 1,618 & 170 & 1,788 & 1,804 & $-0.89 \%$ \\
\hline SEES & 225 & 53 & 278 & 288 & $-3.47 \%$ \\
\hline STS & 1,657 & 212 & 1,869 & 1,872 & $-0.16 \%$ \\
\hline ULS & 5,633 & 318 & 5,951 & 6,009 & $-0.97 \%$ \\
\hline WESS & 638 & 55 & 693 & 724 & $-4.28 \%$ \\
\hline WSS & 758 & 62 & 820 & 896 & $-8.48 \%$ \\
\hline
\end{tabular}




\title{
Message from the Vice-President
}

\author{
Maureen Sullivan \\ Vice-President / President-Elect
}

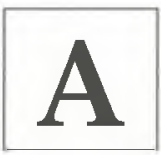

$\mathrm{s}$ the millennium approaches and academic library leaders and their colleagues seek ways to address the complex issues brought about by the rapid changes in technology, the exponential growth of information, and changing organizational structures, librarians will continue to search for strategies and solutions that will improve the products and services they deliver to enhance learning, teaching, and research. As a result, an important component will be training and professional development.

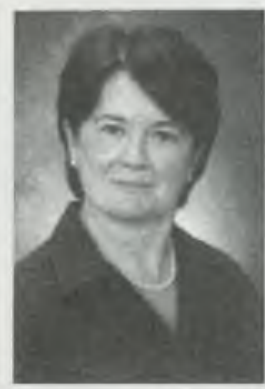

Maureen Sullivan

Academic librarians look to organizations such as ACRL to provide leadership and to establish frameworks where continuous learning can take place. They will also expect these organizations to develop activities that help them acquire the skills and knowledge needed.

In 1998-99, ACRL will have professional development as its area of focus. Legislative advocacy for issues affecting academic librarians and higher education and collaboration with other professional organizations will continue to be important elements of our program activities for the year. The theme for my presidency, "Leadership and Learning," will provide a framework for consideration of the role of academic librarians as campus leaders. A variety of activities planned throughout the year will give us opportunities to reflect upon what leadership means in our work and in our relationships with constituents and colleagues, as well as an opportunity to consider how and what we learn.

The Professional Development Committee will provide the framework and guidance for the creation of an ACRL professional development plan. Their work will begin with the identification of the various activities already underway, as well as the critical elements of a comprehensive program. With the ACRL National Conference, an activity in place since 1978, and other existing programs such as preconferences and Annual Conference programs, ACRL's professional development program has continued to expand. With the recent focus on leadership, ACRL has developed a Leadership Institute for middle managers, and this year will include the professional development program to include the ACRL/Harvard Leadership Institute for senior level academic library leaders, the Institute for Information Literacy's (IIL) Immersion '99 Program, an intensive training and education session for instruction librarians, and a series of audioseminars on such topics as outsourcing, licensing, and negoti- 


\section{Message from the Vice-President}

ating contracts. The ACRL/Harvard Leadership Institute and the IIL's Immersion '99 Program will be presented in July 1999.

The 1999 Annual Conference in New Orleans will feature 16 programs presented by ACRL sections and committees. The keynote speaker for the ACRL President's Program will be Margaret J. Wheatley, president of the Berkana Institute and the author of Leadership and the New Science. Wheatley's exploration of new science principles as they relate to leadership and organizational change offers a new lens through which to view organizational experience and development.

James J. O'Donnell, professor of classical studies and vice provost for information systems and computing at the University of Pennsylvania, will lead the President's Program discussion group at Midwinter. O'Donnell is the author of the recently published Avatars of the Word: From Papyrus to Cyberspace.

The ACRL Strategic Plan will be reviewed and revised this year through engagement of ACRL leaders and the general membership. A planning retreat at the Midwinter Meeting will produce key elements for an ACRL vision for 2005 and a set of proposed strategic directions.

I look forward to seeing many of you throughout the year as I visit with your chapters and libraries. I also hope to see you at the ALA Midwinter Meeting in Philadelphia. I am certain that I will see, if not all of you, most of you at our 9th National Conference in Detroit in April. The National Conference Program Committee has put together a first-rate program consisting of keynote, concurrent, and invited speakers sessions along with many networking and fun activities such as poster sessions, table topics, receptions, and lunches. 


\section{Althea H. Jenkins \\ EXECUTIVE Director}

I

$\mathrm{n}$ a climate of shifting paradigms and values within the library and higher education communities, we must prepare for new models of leadership, service, learning, teaching, and research. Nowhere is this shift more vividly played out than in libraries on campuses across the United States.

Throughout the year, ACRL President W. Lee Hisle

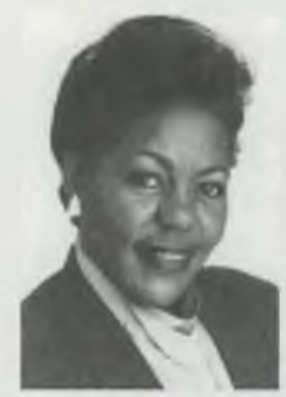

Althea H. Jenkins focused the attention of the Association on how change may be affecting the values of our profession. To address his theme, "Facing the Millennium: Values for the Electronic Information Age," Hisle engaged members in programs, discussion sessions, articles, editorials, and focus groups as they explored their personal values and those of the profession. Hisle emphasized that to respond adequately to the current issues, librarians needed to understand the relationship between traditional values and current conditions.

To facilitate the many discussions about values, ACRL provided publications, the Midwinter discussions, Annual Conference programs, and chapter affiliate meetings to inspire colleagues to explore personal and professional values such as service, intellectual freedom, equity, access, and information literacy.

Members used the pages of CERL News to explore and share insights. John Collins identified a "third wave" where he shared his view on the values of libraries as the embodiment of the democratic ideal. Frances Maloy wrote about the Internet and censorship and compared filtering to knowingly excluding relevant primary and secondary reference source material from users. Katherine Branch addressed the value of reading and reminded academic librarians that reading is within our purview. Stan Campbell reminded us of our love for the book as "object."

A Midwinter discussion session entitled: "Enduring Values for the New Millennium" provided an opportunity for more than 80 participants to identify and prioritize their values. The Annual Conference President's Program theme: "The Value of Values: Changes and Continuities as We Face the New Millennium," was addressed by keynoter William H. Gass, who observed that "the information highway has no destination," and that "misinformation alley" is an apt term for the Internet.

In addition to our focus on values, ACRL members and staff have focused on other important issues and topics for our mission.

ACRL has worked during the past months to position itself as a strategic partner with higher education associations. ACRL brings to this 


\section{Letter from the Executive Director}

partnership an expert knowledge about library and information issues and an ability to address them. Identifying and sharing the roles that libraries and librarians play in accomplishing campus missions is at the heart of the work ACRL does with the higher education organizations. We are most proud of being active partners with AAHE, UCEA, AECT, and ARL/SPARC as demonstrated through our work on their commissions, boards, working groups, and conference programs.

Librarians are expected to provide access, select tools, structure information, and instruct users. In response to this part of its mission, ACRL established the Institute for Information Literacy, which has throughout the year involved faculty, administrators, and campus leaders in its planning process. The ACRL Council of Liaisons has several members serving on commissions, councils, and Boards of Directors of higher education to share ideas and information about how librarians can be helpful to their missions.

ACRL used the 1997-98 ACRL Priorities to establish performance indicators for the year. The performance indicators and a summary of implementation are on the ACRL Web site at http://www.ala.org/ acrl.html.

ACRL has identified four priority areas on which to focus our work and initiatives for 1998-99. They are:

- updating the strategic plan,

- providing professional development,

- building relationships with higher education,

- developing legislative and policy advocacy role.

I want to celebrate our volunteer leadership as epitomized by their service on ACRL's Board of Directors, committees, sections, and discussion groups. I also want to recognize the chapter chairs, vice chairs, and many others who provide support for these offices. Without the dedication and commitment of all of our members, staff, and supporters across the country, this organization could not flourish.

Finally, I want to express my gratitude to all of our donors who sponsored programs, special events, and awards. We are especially appreciative of your generosity. By contributing to ACRL, you have helped us support the enhancement of academic librarians' ability to provide excellent resources and services to their constituents. 


\section{Year in Review}

\section{A}

CRL conducted its third membership needs survey in fall 1997. Previous surveys were administered in 1989 and 1993. Objectives identified for the survey were: 1) to develop a demographic profile of ACRL's membership; 2) to evaluate association programs and activities; and 3) to identify areas for developing new programs and services.

Key findings of the survey indicated that: 1) ACRL's membership is aging; 2) the number of interest sections members participate in has decreased; 3) the ACRL National Conference and Chapters programs are the preferred method of delivery for continuing education; 4) print format is preferred for ACRL publications; and 5) keeping abreast of technological change is the most critical issue facing librarians.

\section{Professional development}

Providing professional development activities so that academic librarians and other information professionals can enhance their ability to do their jobs remains at the core of ACRL's strategic goals. During 1997-98, entry-level, mid-career, and senior-level library personnel participated in more than 57 preconferences, conference programs, workshops, and institutes sponsored by ACRL and its chapter affiliates. In addition, opportunities for learning were available through two videotapes of ACRL programs presented at the 1997 ALA Annual Conference. These videotapes circulated 43 times through interlibrary loan from the ALA headquarters Library and Research Center.

\section{Institutes and programs}

The question of leadership among academic librarians occupied an important spot on the ACRL agenda. Acting on the assumption that good leadership results from learned behaviors, practices, and adopted principles ACRL engaged its members in education activities designed to strengthen their leadership skills, whether conducting the work of the association or carrying out the activities in their libraries in support of campus missions.

- At both the Midwinter Meeting and the Annual Conference Leadership Council, planning sessions were sponsored by the ACRL Board for the purpose of engaging all ACRL leaders in discussions about the future of the association, the current strategic plan, and how the work their units are doing can support the plan.

- Orientation for new leaders was another important leadership development activity in ACRL. A two and one-half hour session designed to provide a conceptual framework of leadership in ACRL was held for newly elected section vice chairs, committee chairs, and board members during the 1998 ALA Annual Conference.

- ACRL values members who have served the association in leadership roles. As an expression of appreciation, and to take advantage of the leadership knowledge and skills among this group, the ACRL Board 
established the ACRL Fellows. Under the leadership of the ACRL's immediate past president, members of the group will meet during the year to define a role and identify activities or issues it can undertake in support of ACRL's mission.

- To help librarians acquire the skills that will enable them to assume leadership roles on their campuses, ACRL established two leadership initiatives. The ACRL Leadership Toolkit Institute was developed to provide practical advice to academic librarians on selected topics in leadership, such as managing change, team-building, presentation skills, negotiations, and managing meetings. The first institute was held in Boston in the spring of 1998 and had an attendance of 147.

- The ACRL/Harvard Leadership Institute is designed to support the development of leadership skills among librarians who hold senior management positions in academic libraries. The Institute's curriculum is currently being developed and plans for a July 1999 four-day session are being completed.

The higher education community is beginning to recognize that for a world in which the information base is more than doubling every six months, it is not enough to simply put a computer at every student's fingertips. Students must be able to problem-solve and think critically in their chosen areas of study. Librarians will be the group expected to provide the link between an expanding knowledge base, technology, and learning. ACRL's Institute for

\section{ACRL Leadership Institute}

Attendees enjoyed ACRL's first Leadership Institute, "Build Your Leadership Toolkit" which took place April 30-May 1, 1998. Here are some of their comments:

$\square$

"One of the best professional meetings I've been to in years."

- "Overall a very useful experience; it gave me ideas about leadership and how I can lead from my nonmanagerial position."

- "A good topic-these topics are not covered in any other library forum."

- "Excellent! Please do it again." Information Literacy is addressing this imperative.

During the last year the advisory group developed its mission and goals and identified initiatives that it would carry out over the next three years as follows:

Professional development for librarians is an intensive immersion program that provides two tracks for intensive training and education. One track is for new librarians and librarians new to teaching. The other is for mid-career instruction librarians who will assume a leadership role in information literacy in their institutions or communities. The first Immersion Program is being held July 23-28, 1999, on the campus of Plattsburgh State University of New York.

Institutional Strategies: "Best Practices" is a program designed to assist individual institutions in developing strategies for developing and implementing effective information literacy programs. Institutions with best practices will be identified and campus teams will be established to evaluate literacy programs against these newly identified practices.

The Community Partnerships Program provides opportunities for a combination of community partners (i.e., academic and $\mathrm{K}-12$; academic, $\mathrm{K}-12$, 


\section{Year in Review}

and public, etc.) to work toward instituting community-based information literacy programs.

\section{National Conference}

One of the busiest schedules ever has been developed for ACRL's 9th National Conference in Detroit, April 8-11, 1999. A full array of speakers, research, panels, networking opportunities, and special events will keep attendees learning and networking the entire time they are in Detroit. New additions to the program include a "conference-within-a-conference" that encourages librarians, faculty, and academic administrators to attend as teams and focus on student learning in an information age. Papers developed by six leaders in higher education will be posted on the Web prior to the conference so discussion of issues, such as scholarly communication, distance learning, the economics of information, and changes in higher education, can begin before the first attendee arrives in Detroit. Nine preconferences have been developed on leadership, instruction, networks, patents, and learning to give librarians an opportunity for more in-depth learning.

\section{ACRL AWARD WINNERS 1998}

- ACRL Academic or Research Librarian of the Year Award (Donor: Baker \& Taylor Books)

Allen B. Veaner, University of Arizona

- ACRL/ALCTS/LAMA/LITA Hugh Atkinson Memorial Award Arnold Hirshon, Lehigh University

- Doctoral Dissertation Fellowship (Donor: Institute for Scientific Information) Jeanine M. Williamson, University of North Carolina-Chapel Hill

- Samuel Lazerow Fellowship for Research in Acquisitions or Technical Services in an Academic or Research Library (Donor: Institute for Scientific Information)

Dilys E. Morris, Iowa State University

- K. G. Saur Award for best C\&RL article (Donor: R. R. Bowker)

Jane P. Kleiner, Louisiana State University $\mathcal{E}$ Charles $A$. Hamaker, University of North Carolina

- EBSCO Community College Learning Resources Leadership Award (Donor: EBSCO Subscription Services)

Leadership: Bernard Fradkin, College of DuPage

Program: Oakton Community College, Internet Training Program
- Distinguished Education and Behavioral Sciences Librarian Award Eva L. Kiewitt, Regent University

- Miriam Dudley Instruction Librarian Award (Donor: JAI Press) Lori Arp, University of Colorado

- IS Innovation in Instruction Award "Health Sciences Information Tools 2000," Wayne State University

- LPSS Marta Lange/CQ Award (Donor: Congressional Quarterly)

Laura N. Gasaway, University of North Carolina-Chapel Hill

- Katharine Kyes Leab and Daniel J. Leab American Book Prices Current Exhibition Catalogue Awards Expensive: "The Reformation of the Bible, The Bible of the Reformation," Southern Methodist University; Moderate: "Kehillat Ha-Kodesh: Creating the Sacred Community: The Roles of the Rabbi, Cantor, Mohel and Shohet in Jewish Communal Life," The Jewish Theological Seminary of America; Inexpensive: "For Love of Ruth," University of Arizona Library

- Martinus Nijhoff West European Specialists Study Grant Jeffrey Garrett, Northwestern University 


\section{Year in Review}

\section{Advancing the Profession}

\section{Awards and Recognition}

ACRL continued a tradition of recognizing and rewarding outstanding achievement and distinguished service in academic librarianship as well as exemplary research and publication. A total of fifteen librarians and their libraries were 1997-98 award recipients. The most prestigious award presented to an academic librarian, "The Academic Librarian of the Year Award" celebrated its twentieth year anniversary with the 1998 award presented to Allen B. Veaner, adjunct assistant professor in the School of Library Science at the University of Arizona. In choosing Veaner for the award, colleagues cited his success as an administrator, author, editor, speaker, consultant, and educator.

The ACRL Board honored ACRL past-president Joseph A. Boisse on his retirement as a university librarian, an outstanding leader in ACRL, and an active member of the American Library Association with a citation and an honorary membership in ACRL.

\section{Standards and Guidelines}

Throughout the year, we continued to review and realign standards and guidelines for the profession. The ACRL Media Resources Committee made extensive revisions to the 1987 "Guidelines for Audio-Visual Services in Academic Libraries" now titled "Guidelines for Media Resources in Academic Libraries." The Distance Learning Section revised its "Guidelines for Extended Academic Library Services." All Standards and Guidelines promulgated and maintained by ACRL members can be accessed on the ACRL's Web site at http://www.ala.org/acrl.html.

An ad hoc committee, Library Outcomes Assessment, appointed by the Board in 1996-97, was charged to develop a philosophical framework for assessing libraries in terms of desired campus outcomes; to develop prototypes for assessment, and to develop a recommendation for one or more processes for implemen-

\section{ACRL Journals}

- Choice-Book review journal of ACRL; 11 issues per year (July/August combined). http:/ / www.ala.org/ $\mathrm{acrl} /$ choice/home.html

- College \& Research Libraries-Official journal of ACRL; six bimonthly issues per year. http: / / www. ala.org/acrl/c\&rl.html

- College \& Research Libraries News-Official news magazine of ACRL; 11 issues per year (July/August combined). http://www.ala.org/ $\mathrm{acrl} / \mathrm{c} \& \mathrm{rlnew} 2 \mathrm{html}$

- Rare Books \& Manuscripts Librarianship-A journal of theory and practice covering all aspects of special collections librarianship; two issues per year. http:// www.ala.org / a crl/ rbmltxt.html tation of the former. The committee completed its work and the Board approved the report submitted which contained the following policy:

The Association of College and Research Libraries recognizes the assessment of outcomes as an integral means of determining the adequacy and quality of libraries and their programs. The association directs its constituent bodies to incorporate this concept into their various activities and policies, including the drafting of ACRL standards and guidelines.

\section{Research and Publications}

While ACRL publications provide some of the best professional development opportunities for academic librarians, they also serve to share in- 


\section{Year in Review}

formation throughout the profession. As the only national membership organization in North America representing all types of academic libraries, ACRL publishes many specialized titles that might not otherwise appear in print. In 1997-98 ACRL maintained its vigorous publications program, publishing four journals and six monographic titles. In addition:

- ACRL participated, along with 24 other disciplinary associations in a study conducted by the

\section{New Titles from ACRL in 1998}

Restructuring Academic Libraries: Organizational Change in the Wake of Technological Change, PIL \#49, Charles A. Schartz, editor

- Choices's Outstanding Academic Books 1992-1997 (the first case bound book published by ACRL) Rebecca A. Bartlett

Academic Library Centrality: User Success Through Service, Access, and Tradition, PIL \#50

Deborah J. Grimes

Designs for Active Learning: A Sourcebook of Classroom Strategies for Information Education Gail Gradowski, Loanne Snavely, Paula Dempsey, editors

- Criteria for Promotion and Tenure for College Librarians, CLIP Note \#26

Virginia Vesper, Gloria Kelley, compilers

ACRL University Library Statistics, 1996-97

Library Research Center, Graduate School of Library and Information Science, University of Illinois at Urbana-Champaign, compiler Syracuse University Center for Instructional Development. The study was designed to extend the range of faculty activities that are rewarded through promotion, tenure, and merit. An advisory committee appointed by the Board developed a statement for academic librarians entitled: "Academic Librarianship and Redefining Scholarship." The Board approved the statement, which ACRL published and distributed.

- In cooperation with the National Forum on Information Literacy ACRL published an update of the 1989 ALA Report on Information Literacy A Progress Report on Information Literacy.

- ACRL's College Libraries Section also produced a videotape entitled, "Hot Topics in College Library Management."

Choice published a special issue, $W E B I I$, a sequel to the highly successful special issue on the Web published in August 1997. The issue contains 482 reviews of web resources plus several original features. The "Web issue" was distributed free to current subscribers, and more than 360 additional copies were sold.

Choice entered an agreement with Doody Publishing of Oak Park, Illinois, for a beta-test of Choice Online. One hundred academic libraries volunteered to participate and 125 political science faculty were selected by the American Political Science Association. The beta-test will end in December 1998, and Choice Online will be launched January 1999. 


\section{Year in Review}

\section{Internet activities}

Our 1997 member survey showed that most ACRL members use the Internet as part of their daily work. This trend fits well with ACRL's move toward a virtual association. During the year, ACRL monitored 13 discussion lists on the ALA server and members from various ACRL units monitored 17 discussion lists that are mounted on servers of various institutions. Web pages were also maintained by sections, chapters, and selected committees and linked to the ACRL Web page. ACRL's web page, now in its 3rd year, was redesigned and expanded during 1997-98 to include a legislative page, Institute for Information Literacy page, and important reports on the issues and topics page. ACRL's web site is among the most often accessed on the ALA server, averaging more than 43,000 "hits" each month. Especially popular is the C\&RL NewsNet job classified ads, which members use to advertise jobs as well as search for the latest openings in the profession.

\section{Addressing the issues}

\section{Government Relations}

The ACRL Government Relations and Information Policy initiative was established by the ACRL Board in 1997-98 for the stated purpose of influencing legislation and public policy affecting academic libraries and higher education. ACRL staff was assigned to this responsibility and given authority to design a program for monitoring activities in this area, preparing analyses of and responses to proposed information policies, examining issues that reflect the interests of academic librarians, and developing positions for ACRL.

Activities in 1997-98 included:

\section{Internet Resource topics in C\&RL News}

theater and performance (9/97)
nealth statistics (10/97)
career development (11/97)
biotechnology resources (12/97)
locating public domain images
(1/98)
investments and personal finance
(2/98)
gateways to social work/welfare
(3/98)
nutrition and vegetarianism
(4/98)
distance education (5/98)
cruising for travel information
(6/98)
East Asian studies (7-8/98)

- Development of ACRL's first legislative/

public policy agenda by the ACRL Government Relations Committee, which was approved by the ACRL Board. The agenda included the following topics: copyright, NGI/Internet II, Title 44, digitization and preservation, National Agricultural Library (NAL), National Endowment for the Humanities (NEH), and appropriations.

- Creation of an ACRL legislative website with links to key government relations and legislative sites of other higher education and information-related organizations.

- Establishment of a legislative network consisting of representatives from each of the 42 ACRL chapters charged with responsibility for developing grass root support and ensuring response to ALA action alerts. In the first six months of activity, more than 80 librarians responded to calls for action and contacted their congressional representatives.

- Adoption of a resolution by the ACRL Board from the Copyright Committee in support of the Ashcroft/Campbell "Digital Copyright Clari- 


\section{Year in Review}

fication and Technology Act" (H.R. 3048). ACRL President W. Lee Hisle wrote a letter to eight higher education organizations, and 2,331 members who are deans or library directors encouraging support of the Boucher/ Campbell copyright proposals.

- Appointment of an ACRL member, Lee Wisel, to the Inter-Association Working Group on Title 44 Revision. The Group was charged to work with congressional staff on draft legislation to revise Chapter 19 on government information dissemination.

- Monitoring and providing support for the

\section{ACRL Council of Liaisons}

- American Association of Community Colleges

- American Association of Higher Education

- American Council on Education

- Association of American Colleges and Universities

- Association of Educational and Communications Technology

- Council of Independent Colleges

- National Association of State University and Land Grant Colleges

- National Forum on Information Literacy

- University Continuing Education Association passage of The Higher Education ACT (HEA) with special attention given to Title VI, International Programs which includes the Foreign Periodicals Program.

- A letter writing campaign by ACRL members in support of increased funding for the $\mathrm{Na}$ tional Agricultural Library (NAL).

- Offering the first ACRL Advocacy Preconference to instruct librarians on how to advocate legislative issues on their campuses, as well as on the national and state level.

\section{Partnerships and Collaborations}

During the year we have continued to strengthen relationships and information exchanges with higher education and information-related organizations. This has served to increase ACRL's visibility as a resource for information about libraries and information sources and services.

During 1997-98, ACRL and its members carried out the following activities:

- As a member of the National Forum on Information Literacy, ACRL produced A Progress Report on Information Literacy: An Update on the ALA Presidential Committee on Information Literacy; Final Report.

- ACRL and the American Association of Higher Education (AAHE) held the first in a series of Higher Education Issues Forums that brought librarians and provosts together to discuss topics of mutual interest.

- ACRL members participated in the development of, and the Board endorsed, a white paper, "Higher Education Policies for the Digital Age" produced by the Higher Education Alliance for Information Technology and spearheaded by the National Association of State Universities and Land-Grant Colleges.

- ACRL members continued to share information on libraries and technology with the higher education community through programs presented at the national conferences of the Middle States Association, Western Association, North Central Association, American Association for Higher Education, and the University Continuing Education Association. 
- At the invitation of the American Council on Education (ACE), the ACRL Board endorsed ACE's statement "On the Importance of Diversity in Higher Education." This statement, endorsed by fifty other organizations, was published in the February 13, 1998, issue of the Chronicle of Higher Education.

- The Task Force on Institutional Priorities and Faculty Rewards, which participated in a study sponsored by Syracuse University, published its report "Academic Librarianship and Redefining Scholarship: A Report from the ACRL Task Force on Institutional Priorities and Faculty Rewards."

- ACRL's Standards and Accreditation Committee surveyed the six regional accrediting agencies to determine procedures employed in selecting academic librarians as peer evaluators on regional accrediting teams. The survey results were reported in CERL News so that librarians with appropriate qualifications may apply to become peer evaluators.

ACRL feels strongly that the challenge of long-term equitable access to scholarly research, especially in the fields of science, technology, and medicine, is a major issue confronting all academic libraries and welcomes the ARL/SPARC initiative as a positive and practical strategy to address some of the complex and difficult issues. SPARC is a newly formed alliance of libraries that aims to foster expanded competition in scholarly communication. The ACRL Board enthusiastically endorsed the SPARC initiative and committed $\$ 5,000$ to support its work. ACRL intends to work closely with ARL to advance the goals and projects of SPARC among academic libraries.

\section{Governing the Association}

The governing body of ACRL is the Board of Directors, which has an obligation to represent the membership in directing the business of the association. The primary functions of the Board of Directors include: clarifying ACRL's mission, establishing both short- and long-range objectives, establishing operating policies, and controlling budgets and fiscal policy.

In addition to carrying out the business of the association in 199798, the following activities received special attention by the Board:

- Revision of the Association's Bylaws and ratification by the membership.

- Allocation of $\$ 35,000$ in the 1998-99 budget for awarding scholarships to minority and entry-level librarians to increase their participation in ACRL's professional development activities.

- Review of previous year's programs and activities, establishment of priorities for 1998-99, and performance indicators for program assessment of the year's activities.

- Establishment of a framework and schedule for updating the strategic plan. 


\section{Year in Review}

\section{Annual Conference Programs and Preconferences}

- ACRL preconference - "Advocacy Training for Academic Librarians: From Ivory Towers to Halls of Power"

- ACRL President's Program- "The Value of Values: Changes and Continuities as We Face the New Millennium"

- ACRL Anthropology \& Sociology Section-"Research 2001: Learned Societies Facilitating Information Awareness and Dissemination in Sociology and Anthropology"

- ACRL Arts Section- "Local Traditions in the Global Village: Are Regional Artistic and Cultural Traditions Threatened by the Development of a Global Information Network?"

- ACRL Asian, African and Middle Eastern Section; Women's Studies Section; International Relations Committee - "A World in Motion: Refugees and Resources"

- ACRL College Libraries Section- "When Education Becomes a Business, What Happens to Traditional Library Values?"

- ACRL Copyright Committee - "Fair Use-A Value in the Digital Age?"

- ACRL Education and Behavioral Sciences Section; ALA Committee on Legislation, Task Force on America Reads; U.S. Department of Education; National Library of Education- "Equity in Education in the Electronic Age"

- ACRL English and American Literature Section; Rare Books and Manuscripts Section; Electronic Text Centers Discussion Group - "Re-Imag(in)ing the Text: The Literary Text in the Electronic Age"

- ACRL Extended Campus Library Services Section; Community and Junior College Libraries Section; ACRL Copyright Committee - "Library Services to Distant Students: Values, Ethics and Cooperation"

- ACRL Instruction Section, preconference- "Learning to Teach: Workshops on Instruction" and "Research with a Small r: Approaches for the Instruction Practitioner"

- ACRL Intellectual Freedom Committee- "Internet Policy and Your Academic Library"

- ACRL Law and Political Science Section- "Bridging an Understanding: The U.S. and the Middle East"

- ACRL Leadership Development Committee- "Enhancing Your Leadership Toolkit"

- ACRL Professional Enhancement Committee- "The Power to Shape our Future: Advocacy and Leadership Skills for Academic Librarians"

- ACRL Racial and Ethnic Diversity Committee- "Diversity and Demographics: Are We Ready for the $21^{\text {st }}$ Century?"

- ACRL Rare Books and Manuscripts Section, preconference- "Getting Ready for the $19^{\text {th }}$ Century: Strategies and Solutions for Rare Book and Special Collections Librarians"

- ACRL Slavic and East European Section- "The Future of Area Studies Librarianship"

- ACRL Technology and the Arts Subcommittee; LITA Arts Committee-"Performing Arts Across the Country: The Digital Stage"

- ACRL University Libraries Section; Science and Technology Section- "Engineering the Future: A New Look at Organizational Thinking and Hyper-Learning"

- ACRL Western European Specialists Section; Arts Section- "Digitizing a Continent: National-Level Planning for Western European Libraries" 


\section{ACRL Board of Directors, 1997-98}

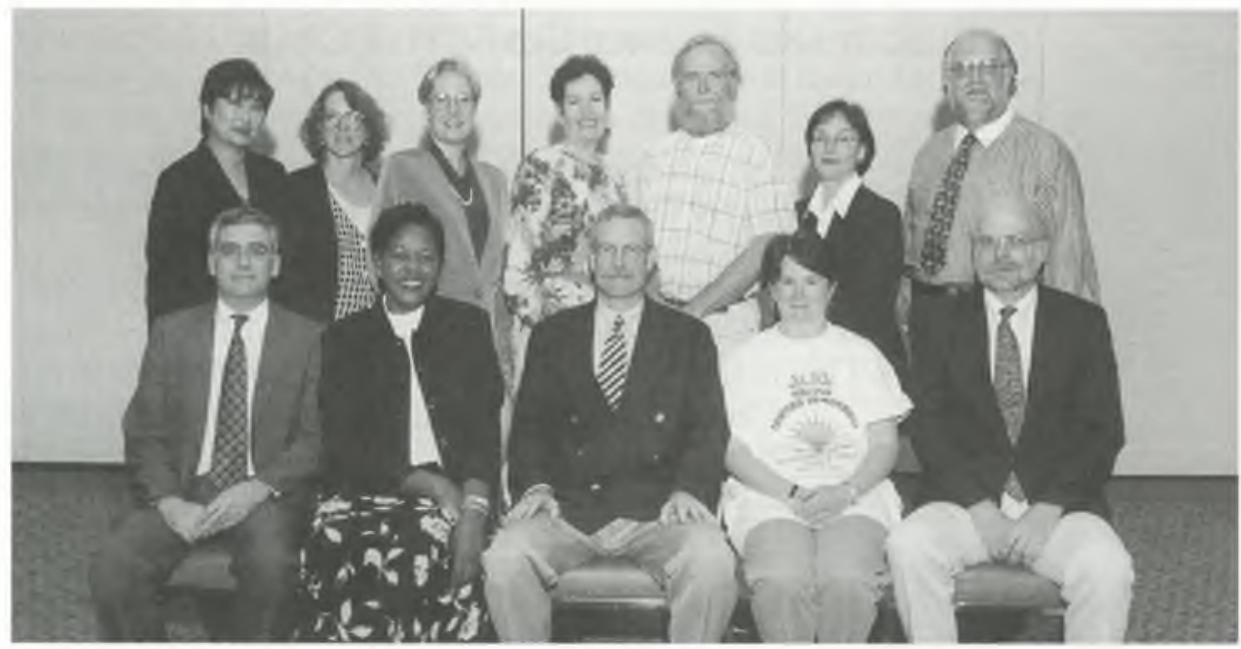

(I to r): (back row) Linda Muroi, Carol Pfeiffer, Helen Spalding, Jill Fatzer, John Sheridan, Victoria Montavon, Bernard Fradkin; (front row) William Miller, Althea Jenkins, W. Lee Hisle, Maureen Sullivan, and Ray English. Not pictured: Mary Reichel.

\begin{tabular}{|l|}
\hline \multicolumn{1}{|c|}{ ACRL Board of Directors, 1997-98 } \\
President: \\
W. Lee Hisle, Austin Community College \\
Vice-President/President-Elect: \\
Maureen Sullivan, Organizational Development Consultant \\
Past-President: \\
Williarn Miller, Florida Aflantic University \\
Budget \& Finance Committee Chair: \\
Ray English, Oberlin College \\
ACRL Councilor: \\
Helen Spalding, University of Missouri-Kansas City \\
Directors-at-Large: \\
Jill B. Fatzer, University of New Orleans \\
Bernard Fradkin, College of DuPage \\
Victoria Montavon, Wright State University \\
Linda S. Muroi, San Diego State University \\
Carol M. Pfeiffer, University of Virginia \\
Mary Reichel, Appalachian State University \\
John Sheridan, Colorado College \\
Executive Director (ex-officio): \\
Althea H. Jenkins, ACRL/ALA \\
\end{tabular}




\section{Financial Report}

\section{RAY ENGLISH \\ Budget and Finance Committee Chair}

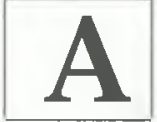

CRL had an exceptionally strong budget performance during the 1997-98 fiscal year and the association's financial condition remains very healthy.

The 1997-98 ACRL budget called for expenditures totaling $\$ 367,838$ above revenues, reflecting the costs of new initiatives and the need to incur expenses in advance of the Detroit National Conference. A combination of strong revenues (particularly from publication advertising) and cost efficiencies resulted in actual spending that was only $\$ 77,622$ above revenues. As a result, the ACRL fund balance finished the year at $\$ 1,295,731$, more than $\$ 290,000$ above the anticipated level. The Choice budget finished the year with a surplus of $\$ 119,249$, almost $\$ 230,000$ above budget.

\section{7-98 budget highlights}

ACRL's revenues (not including Choice) were $\$ 202,531$ more than budgeted for the year. Classified and product advertising revenues, especially from College EResearch Libraries News, were \$118,336 above budgeted levels, accounted for most of the revenue gain. Revenues from preconference and institute registration fees were $\$ 34,012$ more than budget, and donations accounted for over $\$ 20,000$ additional revenues. Subscription revenues for College $\mathcal{E}$ Research Libraries and CERL News were $\$ 12,971$ and $\$ 5,184$ above budget respectively. ACRL membership dues revenues remained stable.

As has been the case in recent years, ACRL realized substantial cost containment in several areas. ACRL's total expenses (again not including Choice) were $\$ 87,685$ less than budget, with a substantial portion of the savings coming in staff costs.

Choice's budget performance in 1997-98 was especially strong. Total Choice revenues were $\$ 75,231$ above budget and expenses were $\$ 155,370$ below budget. Choice's revenue exceeded budget in all categories, except for royalties and miscellaneous sales; advertising sales were $\$ 77,189$ more than budget. Savings in Choice expenses resulted from reduced staff costs and a revised way of accounting for the Unrelated Business Income Tax (or UBIT), which had negatively impacted the budget in the previous fiscal year.

\section{ACRL asset management}

ACRL's long-term investment portfolio includes the ACRL general endowment, the Choice endowment, and three awards endowments 
(Oberly, Leab, and Atkinson). At the end of the 1997-98 fiscal year, the total portfolio value of all ACRL endowment funds was $\$ 628,174$, an increase of $\$ 278,866$ (or $79.8 \%$ ) above the total value at the end of 1996 97. Values for each of the endowments as of August 31, 1998, were as follows: ACRL endowment, \$277,106; Oberly award, \$17,045; Leab award, \$23,750; Atkinson award, \$96,853; Choice endowment, $\$ 214,418$.

The implementation of the first phases of ACRL's new approach to managing its financial assets occurred in 1997-98. During the year, $\$ 200,000$ was transferred from the ACRL operating fund balance into the ACRL general endowment, and $\$ 100,000$ was transferred from the Choice fund balance into the Choice endowment. Similar transfers are planned for the 1998-99 budget year.

I am very pleased to report that a joint task force of representatives from the divisions and the ALA Budget Analysis and Review Committee (BARC) has reached agreement on a new set of guidelines for transfers and withdrawals from division fund balances and division endowments. These new guidelines will permit ACRL to draw on a portion of the appreciation of its unrestricted endowments to carry out strategic initiatives. Coupled with the transfers described above, the new guidelines will enable ACRL to realize the twin goals of its new asset management strategy: continuing to build the association's financial resources through long-term investment growth, while also having the flexibility to use a portion of investment income and capital appreciation to carry out the association's most important strategic initiatives.

\section{8-99 ACRL budget}

The ACRL Board, following a recommendation from the Budget and Finance Committee, has approved a 1998-99 ACRL budget with revenues that exceed expenses by $\$ 172,126$ and a Choice budget with expenditures that are $\$ 88,163$ above revenues. Net revenues from the Detroit National Conference account for a substantial portion of the anticipated 1998-99 ACRL net revenue gain. The 1998-99 budget includes projected revenues, expenses, and fund balances as follows:

\section{ACRL}

beginning fund balance

total revenues

total expenses

net

endowment transfers

ending fund balance

\section{Choice}

beginning fund balance $\$ 1,042,981$

total revenues

$\$ 1,931,350$

$\$ 2,019,513$

$(\$ 88,163)$

$\$ 100,000$

$\$ 854,818$

\section{Thanks}

I wish to express thanks to the ACRL Budget and Finance Committee and particularly the ACRL staff for all their work in realizing such excellent budget results for the 1997-98 year and for their continuing ef- 
forts to build ACRL's financial resources, which are essential for carrying out the association's objectives. Members of the Budget and Finance Committee were: Nancy Allen, Katherine Branch (intern), David Brink, Rena Fowler, Cathy Henderson, Janice Kemp, John Popko, Gloriana St. Clair, Lynn Sutton, Sharon Walbridge, Elizabeth Wood (intern), and Juana Young, as well as ex-officio members Maureen Sullivan and Althea Jenkins.

I concluded last year's report by saying that everyone involved with ACRL can feel justifiably proud of our association's financial strength, its superb budget performance, and ACRL's increased ability to carry out its highest priorities. Those same words hold true today.

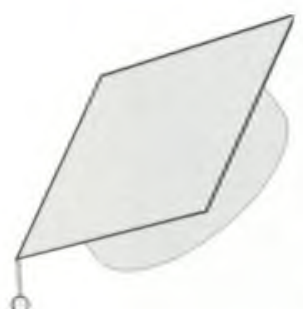

ACRL

\section{Colleagues 1998}

ACRL thanks the corporate community for financially supporting its activities and programs throughout the year. Working together, the academic library and corporate community can achieve goals of mutual interest. Librarians benefit from the expert analysis and problem-solving corporate leaders can bring to issues and topics being addressed.

Corporate contributions added $\$ 39,890$ to the ACRL 1997-98 budget. It was because of these contributions that the ACRL membership enjoyed a wider range of programs and activities. ACRL could not be the major player in the library and higher education arena that it is without the cooperation received from sponsorships.

ACRL's Colleagues program recognizes corporate supporters in two distinct initiatives: corporate giving with a range of $\$ 500-\$ 999$; and enhanced sponsorship with three levels: Summa Cum Laude (donations of $\$ 6,000$ or more), Magna Cum Laude $(\$ 3,000-\$ 5,999)$, and Cum Laude $(\$ 1,000-\$ 2,999)$.

\section{Summa Cum Laude \\ (over $\$ 6,000$ ) \\ EBSCO Information Services \\ Innovative Interfaces}

\section{Cum Laude}

$(\$ 1,000-\$ 2,999)$

ABAA

Brodart

Center for the Book

Elsevier Science Inc.

Haworth Press

\section{Corporate Giving}

(\$500-\$999)

19th Century Shop

Bruce McKittrick Rare Books

Cambridge Scientific Abstracts

Chemical Abstracts

Faxon

Heritage Book Shop

Information Access

Institute for Scientific

Information

Joshua Heller Rare Books

K. G. Saur

Reese Company

Scott Winslow Associates

Swann Galleries Inc.

University Products

Washington Rare Book Group

Yankee Book Peddler 


\section{Financial Report}

\section{Executive Summary 1997-98}

\begin{tabular}{llllc}
\hline SOURCES OF REVENUE & $\begin{array}{l}\text { FY1998 } \\
\text { BUDGET }\end{array}$ & $\begin{array}{l}\text { FY1998 } \\
\text { ACTUAL }\end{array}$ & $\begin{array}{c}\text { PERCENT } \\
\text { OF BUDGET }\end{array}$ & $\begin{array}{c}\text { LAST YEAR } \\
\text { ACTUAL }\end{array}$ \\
\hline
\end{tabular}

\section{Ending Reserve}

Operating Fund (ACRL)

Endowments (ACRL)

\section{$\$ 1,190,604$}

$\$ 1,295,731$

$109 \%$

$\$ 1,573,649$

196,273

414,756

$211 \%$

228,708

Operating Fund (CHOICE)

845,352

$1,042,918$

$123 \%$

$1,024,306$

Endowment (CHOICE)

99,524

213,418

120,598

Subtotal
Membership dues and other
Dues

\section{Dues}

Other

$\$ 2,331,753$

$\$ 2,966,823$

$214 \%$

$\$ 2,947,261$

Awards

$\$ 352,935$

7,000

4,900

Sec. Newsletters

Subtotal

\section{Publications}

CHOICE

C\&RL

C\&RL News

RBML

Nonperiodical Pubs.

Subtotal

\section{Education}

Regional Institute

National

$\$ 30,975$

$\$ 36,515$

$118 \%$

$0 \%$

$\$ 359,060 \quad 102 \%$

$9,525 \quad 136 \%$

$5,600 \quad 0 \%$

2,750

$0 \%$

$\$ 364,835 \quad \$ 376,935 \quad 103 \%$

$\$ 373,552$

Pre-\& Postconferences

\begin{tabular}{lrrrr}
\hline Subtotal & $\$ 88,301$ & $\$ 137,362$ & $156 \%$ & $\$ 1,077,438$ \\
\hline Total Revenue & $\$ 2,930,216$ & $\$ 3,207,978$ & $109 \%$ & $\$ 3,876,824$ \\
CHOICE Revenue & $\$ 1,833,915$ & $\$ 1,909,146$ & $104 \%$ & $\$ 1,768,231$
\end{tabular}

57,326

100,347

$175 \%$

\begin{tabular}{lrrrr}
\hline Subtotal & $\$ 88,301$ & $\$ 137,362$ & $156 \%$ & $\$ 1,077,438$ \\
\hline Total Revenue & $\$ 2,930,216$ & $\$ 3,207,978$ & $109 \%$ & $\$ 3,876,824$ \\
CHOICE Revenue & $\$ 1,833,915$ & $\$ 1,909,146$ & $104 \%$ & $\$ 1,768,231$
\end{tabular}

$\$ 1,768,231$

154,877

359,615

29,259

113,852

\begin{tabular}{lrrrc}
\hline Total Rev. W/O Choice & $\$ 1,096,301$ & $\$ 1,298,832$ & $118 \%$ & $\$ 2,108,593$ \\
\hline National Conference Rev. & $\$ 0$ & $\$ 500$ & $0 \%$ & $\$ 988,315$ \\
\hline $\begin{array}{l}\text { Total Revenue } \\
\text { w/o Natl. Conf. }\end{array}$ & $\$ 1,096,301$ & $\$ 1,298,332$ & $118 \%$ & $\$ 1,120,278$ \\
\hline
\end{tabular}




\section{Financial Report}

\begin{tabular}{|c|c|c|c|c|}
\hline OBJECT OF EXPENSE & $\begin{array}{l}\text { FY1998 } \\
\text { BUDGET }\end{array}$ & $\begin{array}{l}\text { FY1998 } \\
\text { ACTUAL }\end{array}$ & $\begin{array}{l}\text { PERCENT } \\
\text { OF BUDGET }\end{array}$ & $\begin{array}{c}\text { LAST YEAR } \\
\text { ACTUAL }\end{array}$ \\
\hline \multicolumn{5}{|l|}{ Membership Activities } \\
\hline Membership Servs. & $\$ 98,451$ & $\$ 74,668$ & $76 \%$ & $\$ 57,066$ \\
\hline Exec. Comm. \& Board & 98,919 & 93,172 & $94 \%$ & 73,125 \\
\hline Statistics & 11,483 & 11,209 & $98 \%$ & 0 \\
\hline Advisory & 12,097 & $-18,154$ & $-150 \%$ & 15,032 \\
\hline Standards distrib. & 5,263 & 4,298 & $82 \%$ & 5,132 \\
\hline Discussion Groups & 3,222 & 2,854 & $89 \%$ & 2,504 \\
\hline Awards & 33,588 & 23,125 & $69 \%$ & 20,645 \\
\hline Chapters & 60,055 & 50,015 & $83 \%$ & 46,846 \\
\hline Committees & 43,679 & 39,180 & $90 \%$ & 36,059 \\
\hline Sections & 66,082 & 60,298 & $91 \%$ & 55,576 \\
\hline Section Newsletters & 26,352 & 26,223 & $100 \%$ & 25,051 \\
\hline Chapter Topics & 5,916 & 3,957 & $67 \%$ & 3,498 \\
\hline C\&RL & 19,235 & 0 & $0 \%$ & 0 \\
\hline C\&RL News & 1,229 & 0 & $0 \%$ & 0 \\
\hline Council of Liaisons & 69,220 & 48,282 & $70 \%$ & 38,261 \\
\hline Subtotal & $\$ 554,791$ & $\$ 419,127$ & $76 \%$ & $\$ 378,795$ \\
\hline \multicolumn{5}{|l|}{ Publications } \\
\hline CHOICE & $\$ 1,944,537$ & $\$ 1,789,167$ & $92 \%$ & $\$ 1,772,962$ \\
\hline C\&RL & 146,332 & 154,531 & $106 \%$ & 143,658 \\
\hline C\&RL News & 322,553 & 326,867 & $101 \%$ & 282,357 \\
\hline RBML & 27,163 & 33,803 & $124 \%$ & 27,385 \\
\hline Nonperiodical Pubs. & 129,585 & 140,806 & $109 \%$ & 112,124 \\
\hline Subtotal & $\$ 2,570,170$ & $\$ 2,445,174$ & $95 \%$ & $\$ 2,338,486$ \\
\hline \multicolumn{5}{|l|}{ Education } \\
\hline Pre \& Postconferences & $\$ 65,189$ & $\$ 101,272$ & $155 \%$ & $\$ 88,519$ \\
\hline National $(95,97)$ & 155,785 & 125,659 & $81 \%$ & 563,168 \\
\hline Leadership Institute & 30,108 & 34,233 & $114 \%$ & 0 \\
\hline IIL & 32,633 & 40,156 & $123 \%$ & 0 \\
\hline Subtotal & $\$ 283,715$ & $\$ 301,320$ & $106 \%$ & $\$ 651,687$ \\
\hline UNALLOCATED ADMIN. & 0 & $\$ 0$ & $0 \%$ & $\$ 0$ \\
\hline TOTAL EXPENSES & $\$ 3,408,676$ & $\$ 3,165,621$ & $93 \%$ & $\$ 3,368,968$ \\
\hline CHOICE EXPENSES & $\$ 1,944,537$ & $\$ 1,789,897$ & $92 \%$ & $\$ 1,772,962$ \\
\hline CHOICE Net & $(\$ 110,622)$ & $\$ 119,249$ & $-108 \%$ & $(\$ 4,731)$ \\
\hline CHOICE ENDOW. TRANSFER & $\$ 100,000$ & $\$ 100,000$ & \$o & $\$ 100,000$ \\
\hline TOTAL EXP. W/O CHOICE & $\$ 1,464,139$ & $\$ 1,376,454$ & $94 \%$ & $\$ 1,596,006$ \\
\hline Net w/o CHOICE & $(\$ 367,838)$ & $(\$ 77,622)$ & $21 \%$ & $\$ 512,587$ \\
\hline Net w/o Natl. Conference & $(\$ 212,053)$ & $\$ 48,037$ & $-23 \%$ & $\$ 557,110$ \\
\hline ACRL ENDOW. TRANSFER & $\$ 200,000$ & $\$ 200,000$ & & $\$ 0$ \\
\hline
\end{tabular}




\section{Meet the ACRL Staff}

Many of you have had phone and/or e-mail contact with ACRL's staff, of which there are 12.95 ALA-approved FTE positions at headquarters. Here's your chance to put a face with that voice or e-mail signature. On these pages, we present current ACRL staff (including two of ACRL's Choice 22.4 FTE staff) with information about their responsibilities. Take a minute to "meet the staff!" We're looking forward to hearing from you.

With several vacant positions in ACRL, we reviewed and made changes in the distribution of duties and responsibilities, some of which should result in higher grade levels and promotions for existing employees. New ACRL and Choice staff in 1998 include: Margaret Sutton, professional development assistant (ACRL); Gail Skamarack, general manager (Choice); Susanne Bjorner, special projects editor (Choice); Helena Tench, social sciences editor (Choice); Sharon Coleman, distribution assistant (Choice)

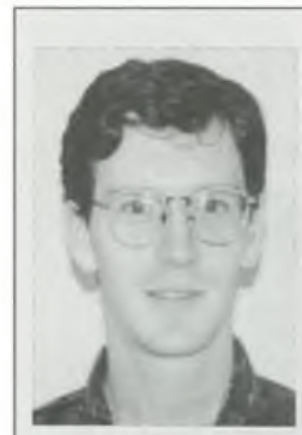

JACK BRIODY, design/production assistant, manages CERL production; develops and maintains ACRL Web pages; coordinates the awards program; designs and produces section newsletters; maintains ACRL lists on the ALA servers; and produces and maintains ACRL standards, guidelines, and model statements. Phone: (312) 280-2516; e-mail: jbriody@ala.org.

MARY ELIEN K. DAVIS, senior associate executive director, is editor of CERL News; coordinates professional developnent activities including National Conference program and meeting logistics, institutes, preconferences, workshops; manages day-to-day operations of ACRL; and is the official contact in the absence of the executive direc

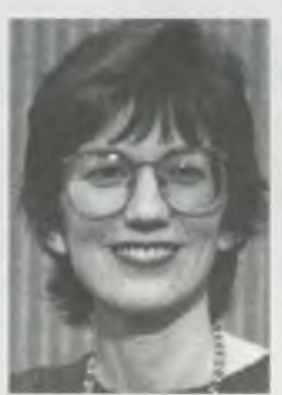
tor. Phone: (312) 280-2511; e-mail: medavis@ala.org.

FRANCINE GRAF, managing editor of Choice, manages all editorial aspects of the magazine, reviews-oncards, and electronic databases; coordinates the work of Choice's editorial staff; plans the editorial calendar; and handles Choice's business and economics sections. Phone: (860) 347-6933; email: fgraf@ala-choice.org.

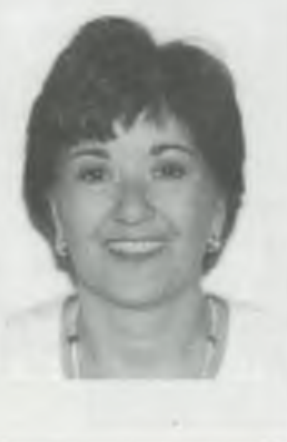

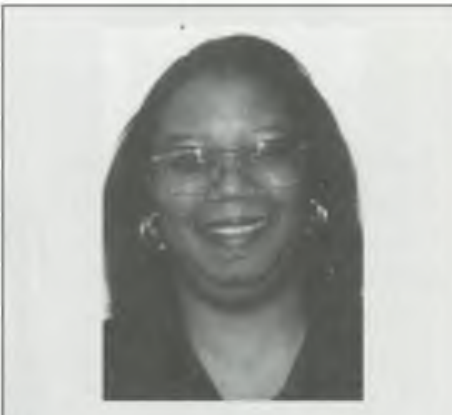

DARLENA DAVIS, administrative secretary, prepares slates and ballots and chapter and section rosters; prepares members' requests for reimbursements; prepares all Annual Conference speakers letters of agreement; maintains member services files and archives; and assists with member services activities Phone: (312) 280-2519; e-mail: ddavis@ala.org. 


\section{Meet the ACRL Staff}

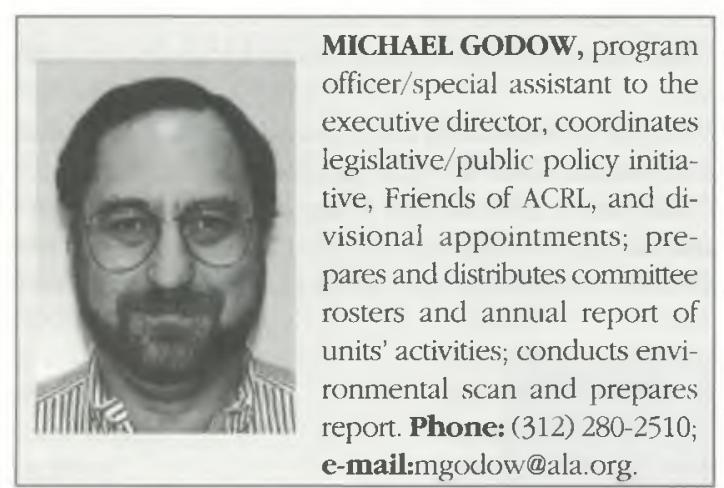

JACK HELBIG, classified atd manager, maintains ACRL job ads on the Wel); manages and sells ad space in CERL Neu's for library job announcements. Phone: (312) 280-2513; fax: (312) 2807663; e-mail: jhelbig@ala. org.
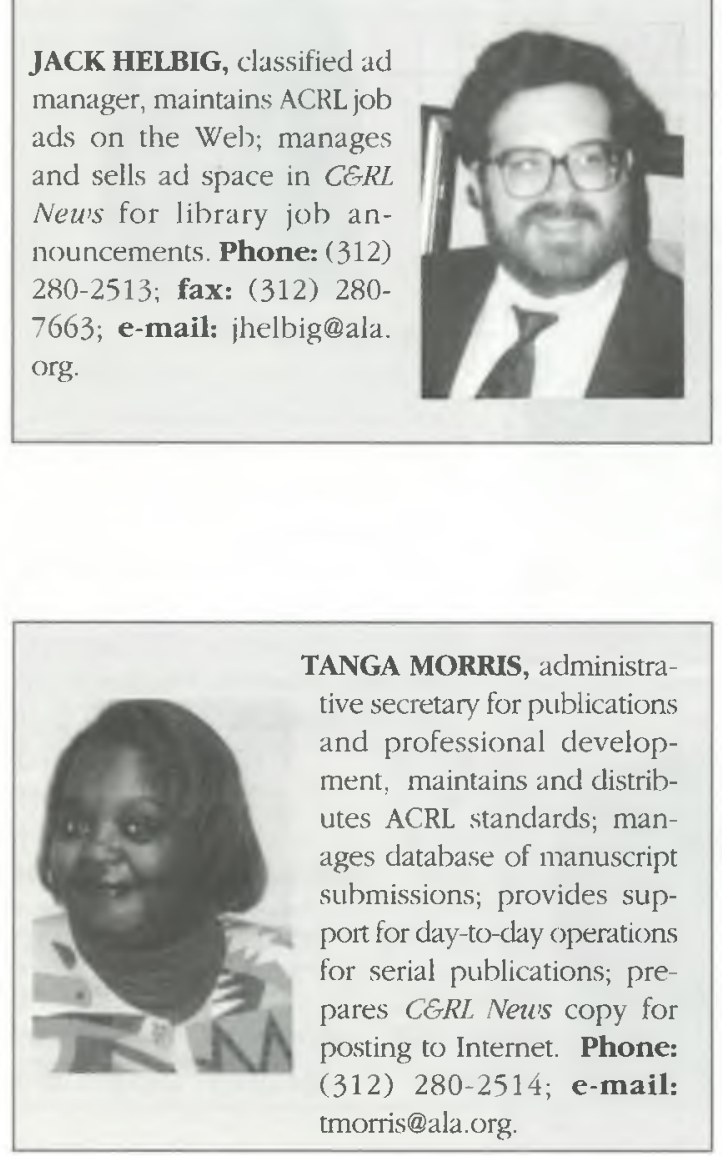

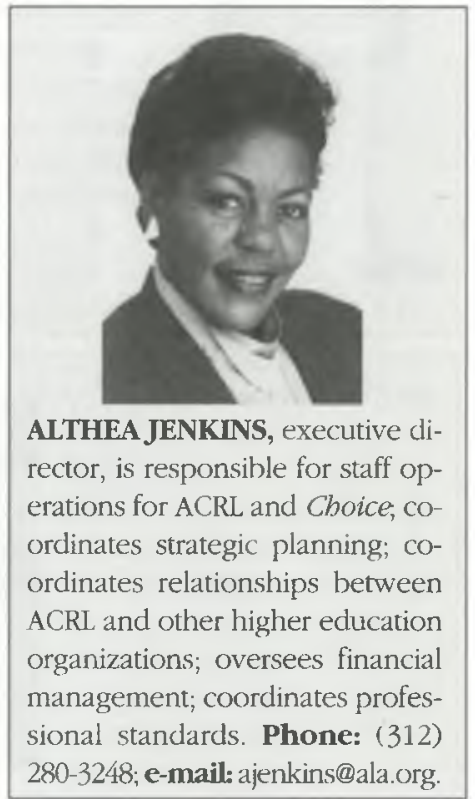




\section{Meet the ACRL Staff}

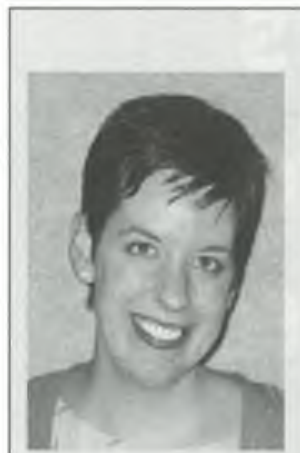

MARGOT SUTTON, professional development assistant, handles ACRL special events planning for Midwinter Meetings and Annual Conferences; ACRL preconferences, National Conferences, and institute planning; and maintains the speaker agreement file. Phone: (312) 280-2522; e-mail: msutton@ala.org.
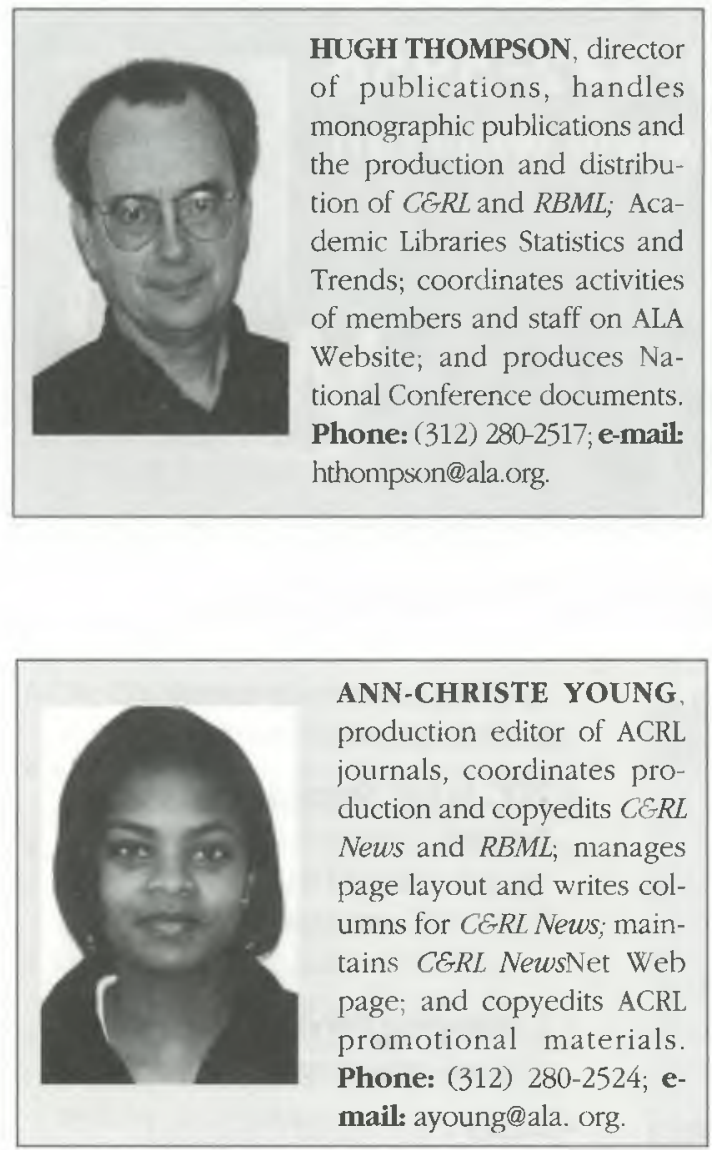

IRVING ROCKWOOD, editor of Choice, is responsible for Choice and other product advertising sales, subscription services, and marketing and promotions. Phone: (860) 347-6933; e-mail: irockwood@ ala-choice.org. 


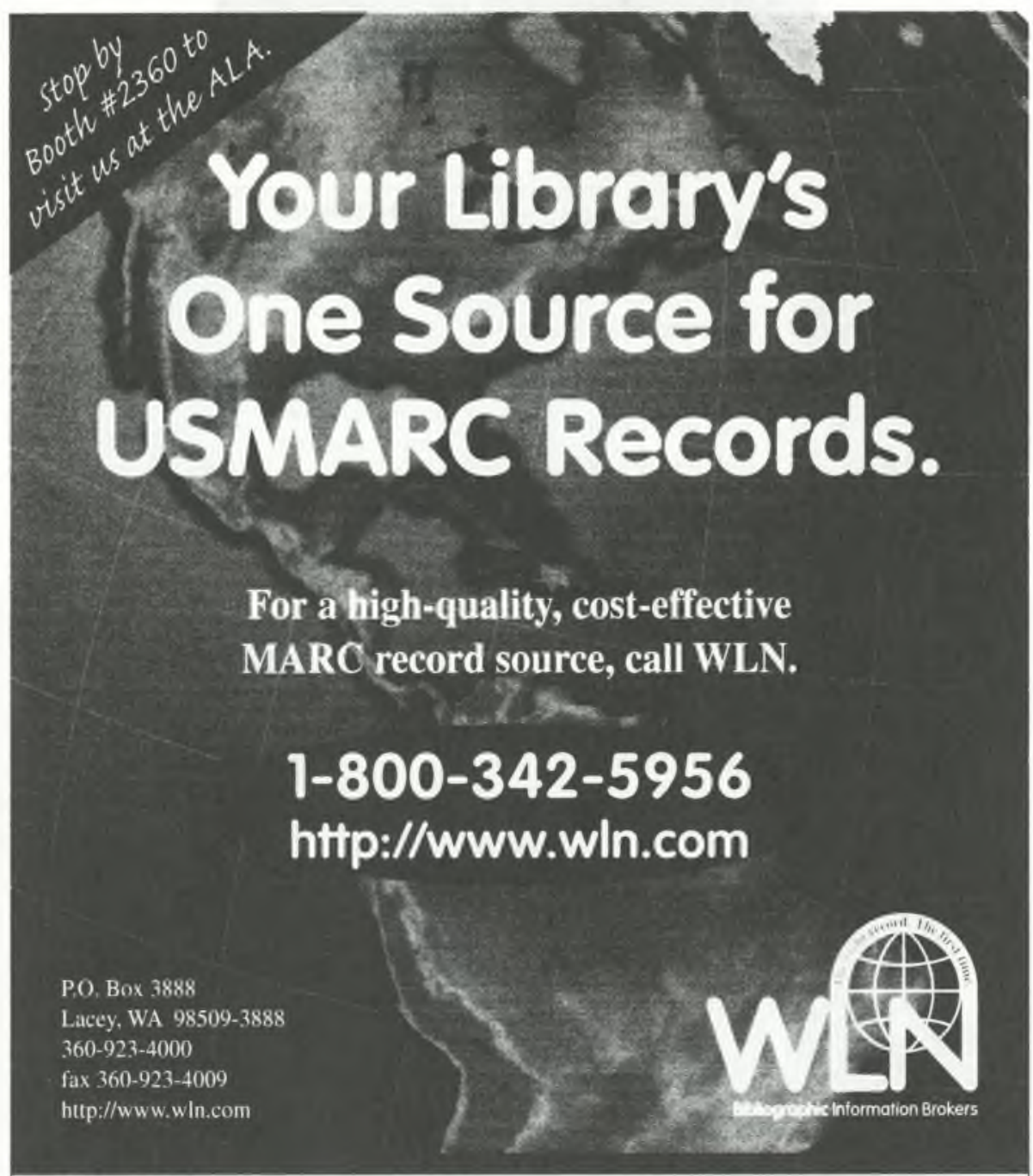

\section{The right record. The first time.}

- WLN Online System - search 11 million USMARC records using either command mode or a graphical interface.

- LaserCat $^{\circ}$ - 4.5 million USMARC records on CD-ROM.

- FastCat ${ }^{*}$ - 1 million USMARC records on CD-ROM specifically selected for school libraries.

- MARC Record Service (MARS ${ }^{\circ}$ ) authority control processing and updating service plus complete database preparation.

- TOC MARC Record Enrichment Service - have your USMARC records enriched with Blackwell's Table of Contents records dating from 1992 forward. NEW!

- Cataloging Services - customized original cataloging services.

- ACAS - Automated Collection Analysis Services. 